УДК 342.9

DOI https://doi.org/10.32837/pyuv.v0i4.626

\author{
Ю.О.Оврамець \\ orcid.org/0000-0002-3695-4848 \\ аспірант кафедри міжнародного та порівняльного правознавства \\ Національного університету біоресурсів і природокористування України
}

\title{
ЗМІСТ ТА ЕТАПИ АДМІНІСТРАТИВНОЇ ПРОЦЕДУРИ АВТОРИЗАЦІЇ ЕЛЕКТРОННИХ МАЙДАНЧИКІВ
}

Актуальність теми. Запроваджена з прийняттям Закону України «Про публічні закупівлі» від 25 грудня 2015 р. № 922-VII (далі - Закон України «Про публічні закупівлі») система публічних закупівель визначає низку відповідних адміністративних процедур. Однак у науковій літературі наразі відсутні комплексні дослідження щодо адміністративної природи процедур публічних закупівель. Що стосується питання адміністративних процедур авторизації електронних майданчиків, то воно взагалі не було предметом самостійних наукових праць в Україні.

Тему авторизації електронних майданчиків у науковій літературі частково зустрічаємо в працях Н.П. Селіванової [33] та Н.В. Кулак [10]. Нині в юридичній літературі точаться гострі дискусії з приводу того, чи слід розглядати публічні закупівлі як інститути адміністративного права.

3 огляду на це особливої актуальності набуває питання виявлення та розуміння структури адміністративної процедури авторизації електронних майданчиків, що дозволить створити передумови для контролю за перебігом адміністративних проваджень, розпочатих із метою реалізації цієї процедури в конкретних правовідносинах між державою та оператором авторизованого майданчика. Малодослідженість окресленої теми робить iї актуальною не тільки на доктринальному, але й на правозастосовному рівні.

Викладення основного матеріалу. Повний перехід від «паперових" торгів на електронний формат державних закупівель відбувся із затвердженням Закону України «Про публічні закупівлі». Наразі електронна система закупівель має дворівневу будову, де є вебпортал Уповноваженого органу з питань закупівель та авторизовані електронні майданчики вебпорталу [3, с. 6]. Ідея дворівневої структури має на меті створення дієвого буфера між державою, з однієї сторони, й користувачами системи (замовниками й учасниками тендерів), - 3 іншої.

Слід звернути увагу, що держава залишила за собою право забезпечувати авторизацію електронних майданчиків, що є важелем впливу на їх операторів (власників). Поняття «авторизація» походить від англійського слова "authorization", яке перекладається як "дозвіл». Авторизація здебільшого є терміном, що використовується в кібер- нетиці, а по змісту є процедурою надання користувачу системи обробки даних (особі, програмі) визначених повноважень у системі, тобто права виконання в ній деяких дій. Також поняття «авторизація» означає керування рівнями й засобами доступу до різних об'єктів і ресурсів системи залежно від ідентифікатора й пароля користувача [35].

Таким чином, авторизація $\epsilon$, по суті, наданням повноважень в інформаційно-телекомунікаційній системі. Для цілей дослідження в розумінні пункту 7 частини 1 статті 1 Закону України «Про публічні закупівлі» такою інформаційно-телекомунікаційною системою є електронна система закупівель «Прозорро». Варто відзначити, що авторизацію в електронній системі закупівель «Прозорро» проходять інші інформаційно-телекомунікаційні системи, що певною мірою не стикується 3 класичним визначенням поняття авторизації, зазначеним вище. Авторизації підлягає користувач, тобто суб'єкт, а не його інструмент - інформаційно-телекомунікаційна система, якою він володіє.

Водночас законодавець свідомо використовує прив'язку терміну «авторизація» до поняття «електронний майданчик» та іде на використання такої юридичної конструкції, хоча фактично доступ до інформаційно-телекомунікаційної системи - електронної системи закупівель «Прозорро»надається суб'єкту - оператору електронного майданчика - засобами його електронного майданчика. Використання цієї конструкції більшою мірою зумовлене тим, що грунтовніші вимоги висуваються до електронного майданчика, й від його працездатності залежить задоволення потреб і його оператора, й адміністратора системи «Прозорро», й кінцевих користувачів - учасників, замовників і спостерігачів публічних закупівель. Окрім цього, необхідно вказати, що саме поняття «користувач» у кібернетиці здебільшого означає певний інформаційний профіль, тобто «маску», за допомогою якої реальний суб'єкт діє в інформаційному просторі інформаційно-телекомунікаційної системи.

Таким чином, авторизація електронного майданчика як певного користувача зі значно розширенішим набором функцій не видається невірною з боку законодавчої техніки й формально-юридичної доцільності вживання такої термінології. У будь-якому випадку як суб'єкт - оператор елек- 
тронного майданчика, так і його власність - електронний майданчик - не можуть отримати доступ до електронної системи закупівель «Прозорро» без проходження процедури авторизації електронного майданчика. Додатковою ілюстрацією тісного зв'язку між наявністю авторизації електронного майданчика й діяльністю його оператора може послужити судова справа № 826/12827/18, із рішень в якій вбачається, що авторизований електронний майданчик був позбавлений авторизації у зв'язку з неналежним виконанням оператором цього майданчика його грошових договірних зобов'язань перед адміністратором електронної системи закупівель. Водночас подальші заходи з оскарження наказу Уповноваженого органу управління про позбавлення акредитації не дали позитивного результату [32; 14$]$.

Авторизації електронних майданчиків проводиться Уповноваженим органом управління, таким чином, відносини з авторизації набувають ознак адміністративно-правових, оскільки основним і постійним учасником таких відносин є адміністративний орган. Уповноваженим органом є центральний орган виконавчої влади, що забезпечує формування та реалізує державну політику у сфері публічних закупівель. Вказаним органом, відповідно до пункту 1 Положення про Міністерство розвитку економіки, торгівлі й сільського господарства України, затвердженого постановою Кабінету Міністрів України від 20 серпня 2014 р. № 459 (у редакції постанови Кабінету Міністрів України від 11 вересня 2019 р. № 838) є Міністерство розвитку економіки, торгівлі й сільського господарства України [13]. Так, підпунктом 107 пункту 4 зазначеного Положення передбачено, що Мінекономіки, відповідно до покладених на нього завдань, проводить авторизацію електронних майданчиків.

3 боку етимології слово «процедура» походить від французького іменника «procedure» - «процедура, процес», який своєю чергою - від дієслова "proceder» - «вчиняти, діяти, походити», яке вийшло 3 латинського "procedere» - «виходити iз, просуватись», де «pro» означає «вперед, для, за, замість», a «cedere» - «йти, ступати». Останне походить з індоєвропейського дієслівного кореня «sed»- «переміщатись, йти» [6, с. 613-614]. 3 боку лексикології «процедура» - це «всяка тривала, послідовна справа, порядок, обряд» [4, с. 526], «встановлена, прийнята послідовність дій для здійснення або оформлення якої-небудь справи» [5, с. 543], «офіційний порядок дій, виконання, обговорення чого-небудь» [12, с. 577], «офіційно встановлений чи узвичаєний порядок здійснення, виконання або оформлення чого-небудь; ряд яких-небудь дій, хід виконання чого-небудь» [34, с. 343].

Наразі в законодавстві України не встановлено дефініції поняття «адміністративна процедура», тому що не врегульовані загальні засади здійснення адміністративних процедур. Однак об’єктивна необхідність у проведенні реформи адміністративних процедур існує вже понад 20 років [11, с. 10]. 3 огляду на це першим заступником Голови Верховної Ради України Р.О. Стефанчуком 25 лютого 2020 р. анонсовано розгляд Верховною Радою України проєкту Кодексу України про адміністративні процедури. Наразі до Верховної Ради України за вказівкою Кабінету Міністрів України подано черговий проєкт закону «Про адміністративні процедури» від 14 травня 2020 р. № 3475 [29]. Вочевидь, в основу вказаного проєкту покладено проєкт закону «Про адміністративні процедури», внесений Кабінетом Міністрів України на розгляд Верховної Ради України 28 грудня 2018 р. (№ 9456) [30], який було відкликано 29 серпня 2019 р. і надалі передано на опрацювання в Міністерство юстиції України й Міністерство цифрової трансформації України. Законопроєкти аналогічного змісту вже вносились на розгляд парламенту: № 8413 від 29 грудня 2001 р. [25]; № 5462 від 29 квітня 2004 р. (відкликаний 08 лютого 2005 р.) [26], № 2789 від 18 липня 2008 р. (відкликаний 08 лютого 2010 р.)[27], № 11472 від 03 грудня 2012 р. (відкликаний 12 грудня 2012 р.) [28].

Вказаний законопроєкт має на меті врегулювати процедури, які застосовуватимуться у відносинах органів виконавчої влади, органів місцевого самоврядування, їх посадових і службових осіб, інших суб'єктів, які згідно із законом уповноважені здійснювати владні управлінські функції, 3 фізичними, юридичними й іншими особами щодо забезпечення реалізації та захисту прав і законних інтересів осіб і виконання ними визначених законом обов'язків, а також повинен регламентувати процедури розгляду адміністративних скарг. Необхідно відзначити, що відповідно до частини 2 статті 1 вказаного законопроєкту оскарження процедур публічних закупівельне не входить до сфери його регулювання. Однак це не означає, що оскарження процедур публічних закупівель не належить до адміністративних процедур у цілому.

Проєкт закону «Про адміністративні процедури» містить поняття адміністративної процедури як визначеного порядку здійснення адміністративного провадження. Зі змісту зазначеного вбачається, що поняття адміністративної процедури розглядається через поняття адміністративного провадження. Там же надано визначення поняття адміністративного провадження як сукупності процедурних дій, послідовно вчинених адміністративним органом, і прийнятих процедурних рішень із розгляду й розв'язання адміністративної справи, що завершується прийняттям i, в необхідних випадках, виконанням прийнятого адміністративного акту. 
На думку спеціалістів Головного науково-експертного управління Апарату Верховної Ради України О.П. Мірошниченка й І.Й. Снігур, одночасне використання вказаних понять у законопроєкті призводить до суперечностей з огляду на їх незрозуміле співвідношення. Учені справедливо зазначають про необхідність отримання відповіді на питання: це адміністративна процедура складається з адміністративних проваджень чи навпаки, адміністративне провадження складається з таких процедур (процедурних дій). На їхню думку, поняття адміністративної процедури як порядку здійснення адміністративного провадження в поєднанні з визначенням адміністративного провадження як сукупності процедурних дій приводить до логічного висновку, що «адміністративна процедура» - це порядок здійснення адміністративних процедур, що некоректно з боку законодавчої техніки [30, с. 7].

На нашу думку, такий висновок дещо передчасний, оскільки «адміністративна процедура»це «порядок», а «адміністративне провадження» - це «сукупність процедурних дій», тобто поняття адміністративної процедури стосується нормативного регулювання діяльності, а поняття адміністративного провадження стосується безпосередньо діяльності, яка потребує такого нормативного регулювання. 3 вказаного не вбачається тотожність понять: адміністративна процедура визначає порядок здійснення адміністративних проваджень, тобто діяльність уповноважених суб'єктів.

Адміністративне провадження повинне бути здійснене в певному порядку, тобто за певною процедурою, в протилежному випадку таке провадження не можна вважати законним. Стосовно адміністративної процедури не можна, як уже зазначалось вище, застосовувати поняття «незаконна», оскільки адміністративна процедура визначає порядок, тобто вона і є законом (за умови дотримання принципу ієрархічності нормативно-правових актів, тобто якщо актами нижчої юридичної сили не порушено норм законодавчих актів вищої юридичної сили). Водночас адміністративна процедура може бути протиправною з огляду на те, що вона може бути побудованою без дотримання принципу верховенства права й порушувати основоположні права людини. Адміністративне провадження може бути як незаконним, тобто здійснюватися не в порядку, встановленому адміністративною процедурою, так і протиправним, якщо здійснюється відповідно до протиправної адміністративної процедури. Однак, якщо адміністративне провадження здійснюється відповідно до вимог адміністративної процедури, що відповідає принципу верховенства права, то таке провадження є і законним, і правовим.
У науковій літературі висловлено декілька думок стосовно співвідношення понять «адміністративна процедура» й «адміністративне провадження». Так, В.К. Шкарупа розглядає вказані поняття як тотожні [36, с. 14]. На думку O.М. Бандурки, вказані поняття співвідносяться як загальне й особливе [1, с. 111]. У розумінні В.П. Тимощука адміністративна процедура виступае як модель адміністративного провадження, натомість адміністративне провадження є власне розгляд і розв'язання конкретної адміністративної справи (тобто конкретна активна діяльність). Ми вважаємо, що останнє зазначене співвідношення найвірніше й таке, що відповідає як духу, так і букві закону. Під адміністративною процедурою повинен розумітись загальний порядок розгляду й розв'язання адміністративних справ адміністративним органом (модель провадження), а під провадженням - уже власне розгляд і розв'язання окремої справи, тобто конкретна діяльність органу.

Таким чином, з огляду на положення статті 2 проєкту закону «Про адміністративні процедури», адміністративна процедура - це визначений законодавством порядок здійснення сукупності процедурних дій, послідовно вчинених адміністративним органом, і прийнятих процедурних рішень із розгляду й розв'язання адміністративної справи, що завершується прийняттям $i$, в необхідних випадках, виконанням прийнятого акту. Вказане визначення відрізняється від визначень, сформульованих науковцями. Першочерговою видається різниця у сфері результатів поняття, де доктринальний підхід результатом адміністративної процедури визначає також адміністративний договір. Кодексом адміністративного судочинства України від 06 липня 2005 р. № 2747-IV надається визначення поняття. Там вказано, що адміністративний договір є спільним правовим актом суб'єктів владних повноважень або правовим актом за участю суб'єкта владних повноважень та іншої особи, що ґрунтується на їх волеузгодженні, має форму договору, угоди, протоколу, меморандуму тощо, визначає взаємні права й обов'язки його учасників у публічно-правовій сфері й укладається на підставі закону:

a) для розмежування компетенції чи визначення порядку взаємодії між суб'єктами владних повноважень;

б) для делегування публічно-владних управлінських функцій;

в) для перерозподілу або об'єднання бюджетних коштів у випадках, визначених законом;

г) замість видання індивідуального акта;

г) для врегулювання питань надання адміністративних послуг [9].

Зі змісту визначення вбачається, що адміністративний договір укладається шляхом застосу- 
вання адміністративної процедури, таким чином, доктринальний підхід знайшов своє втілення в чинному законодавстві. Постає питання про те, чому в законопроєкті «Про адміністративні процедури» не згадуються адміністративні договори. Вважаємо, що це є прогалиною вказаного проєкту закону. Питання підпорядкування адміністративних договорів адміністративній процедурі досить актуальне в контексті теми дослідження, оскільки з боку ретроспективи договори у сфері державних закупівель свого часу розглядались деякими науковцями [31, с. 28-29] як різновид адміністративних договорів. Разом із цим зараз перелік адміністративних договорів визначено нормативно й договори у сфері публічних закупівель прямо до них не належать.

Адміністративна процедура авторизації електронних майданчиків має на меті допуск приватних інформаційно-телекомунікаційних систем до електронної системи закупівель із надання їм повноважень електронного майданчика - повноважень забезпечувати реєстрацію користувачів електронної системи закупівель, автоматичне розміщення, отримання та передання інформації та документів під час проведення закупівель, користування сервісами з автоматичним обміном інформацією. Водночас безпосередньою метою оператора електронного майданчика є отримання винагороди за використання його авторизованого електронного майданчика користувачами - замовниками й учасниками процедур закупівель.

Провівши аналіз доктринальних визначень поняття адміністративної процедури й змісту поняття в проєкті закону «Про адміністративні процедури», вважаємо за необхідне виокремити ключові ознаки поняття адміністративної процедури. На нашу думку, адміністративній процедурі притаманні такі ознаки:

1) адміністративна процедура є визначеним законодавчо порядком дій;

2) вона послідовна (являє собою нормативну модель поведінки);

3) здійснюється особливим суб'єктом - адміністративним органом;

4) спрямована на розгляд і розв'язання адміністративної справи;

5) завершується шляхом прийняття рішення адміністративного органу;

6) рішення оформлюється адміністративним актом (чи адміністративним договором).

Процедурі авторизації електронних майданчиків притаманні всі характерні ознаки адміністративних процедур.

Адміністративна процедура авторизації електронних майданчиків чітко врегульована зі сторони держави. Основним нормативним актом, що детально регламентує сферу авторизації електронних майданчиків, є Порядок функціонуван- ня електронної системи закупівель і проведення авторизації електронних майданчиків, затверджений постановою Кабінету Міністрів України від 24 лютого 2016 р. № 166 [22].

Авторизація послідовна, тобто становить собою певну нормативну модель поведінки. Вона спрямована на розв'язання адміністративної справи, завершується прийняттям адміністративного акту. У залежності від виду авторизації зміст авторизації відрізняється. Наприклад, необхідно відрізняти процедуру авторизації електронного майданчика й процедуру попередньої авторизації електронного майданчика. Так, Міністерство розвитку економіки, торгівлі й сільського господарства України (Уповноважений орган) приймає кінцеве рішення про авторизацію електронного майданчика на підставі відповідного рішення комісії. Своєю чергою оператор авторизованого / попередньо авторизованого електронного майданчика має право оскаржити в судовому порядку рішення Уповноваженого органу щодо відключення його авторизованого / попередньо авторизованого електронного майданчика.

Разом із цим необхідно відзначити, що поняття «попередня авторизація» було запроваджене Кабінетом Міністрів України всупереч положенням Закону України «Про публічні закупівлі» шляхом внесення змін і доповнень до Постанови № 166 Постановою «Про внесення змін до Порядку функціонування електронної системи закупівель і проведення авторизації електронних майданчиків» від 01 липня 2016 р. № 396 [20]. На думку Рахункової палати, всі процедури, функціональні завдання та обов'язки, введені на підставі поняття «попередня авторизація», суперечать Закону України «Про публічні закупівлі». Це дозволило посадовим особам Мінекономрозвитку приймати незаконні управлінські рішення про попередню авторизацію електронних майданчиків і допускати їх до функціонування в складі електронної системи закупівель без створеної комплексної системи захисту інформації (далі - КСЗІ) [8].

Фактично вказана проблема була викликана доповненням пункту 17 Порядку № 166 новим абзацом такого змісту: в разі тимчасової відсутності на вебпорталі Уповноваженого органу технічної можливості проведення передбачених Законом деяких видів процедур закупівлі й / або закупівлі за рамковими угодами Уповноважений орган може прийняти рішення щодо попередньої авторизації електронних майданчиків на підставі відповідного рішення комісії. На перший погляд, висновок Рахункової палати прямо не вбачається з відповідних змін, внесених Кабінетом Міністрів України. Однак є підстави стверджувати, що він був сформований Рахунковою палатою з огляду на певну практику Мінекономрозвитку. Прямо доповнення пункту 7 означають, що якщо в електронній систе- 
мі закупівель «Прозорро» тимчасово відсутні технічні можливості проведення процедур закупівель чи укладення рамкових угод, Мінекономрозвитку проводить попередню авторизацію електронних майданчиків, а не звичайну авторизацію. До моменту отримання атестату відповідності КСЗІ електронною системою закупівель «Прозорро», з огляду на положення частини 2 статті 8 Закону України «Про захист інформації в інформаційно-телекомунікаційних системах" від 05 липня 1994 р. № 80/94-ВР [24], у ній проведення тендерів у цілому не могло здійснюватися. Зазначений крок уповноваженого органу зрозумілий і вимушений, оскільки розробка комплексної системи захисту інформації та отримання на неї атестату відповідності є тривалою за часом, а припинення проведення тендерних процедур не може бути здійснене 3 огляду на відсутність політичної волі керівництва держави, тому що запровадження та функціонування електронної системи закупівель було наслідком запиту українського суспільства. Однак не можна не погодитись із позицією Рахункової палати, висловленою в іншому звіті, про те, що до запровадження КСЗІ в електронній системі закупівель, інформація, що в ній міститься, повинна розцінюватись суспільством як така, що підпадає під ризик неправдивості [7]. Атестат відповідності КСЗІ електронної системи закупівель «Прозорро» Державним підприємством «Прозорро» отримано 15 лютого 2019 р.

Зазначену проблему відсутності КСЗІ в електронних майданчиках було констатовано й у подальших редакціях Порядку № 166. Органічним наслідком її розгортання та спробою розв'язання було прийняття Кабінетом Міністрів України постанови «Про внесення змін до Порядку функціонування електронної системи закупівель і проведення авторизації електронних майданчиків» від 10 липня 2019 р. № 704 [21]. Використання поняття «попередня авторизація» набуло поширення, однак було визначено умови набуття статусу авторизованого майданчика й запроваджено процедуру авторизації попередньо авторизованого майданчика. Таким чином, разом із вказаними змінами сформувалась така система процедур авторизації.

Усі майданчики, що діяли до 15 лютого 2019 р. у складі електронної системи публічних закупівель, мають статус попередньо авторизованих. Для отримання ними статусу авторизованого майданчика вони проходять процедуру авторизації попередньо авторизованого майданчика. Нові майданчики, що мають намір долучитись до системи електронних публічних закупівель у період чинності її атестату відповідності КСЗІ, проходять процедуру авторизації електронного майданчика (первинна авторизація). На період, коли в інформаційно-телекомунікаційній системі (далі - ITC) «Прозорро» відсутній атестат відповідності КСЗІ (наприклад, коли в старого атестату відповідності строк завершився, а новий ще не отримано), нові електронні майданчики проходять процедуру попередньої авторизації.

Останній тип процедури проводився в минулому до 15 лютого 2019 р. i, на нашу думку, більше проводитись не буде, з огляду на те, що Державне підприємство «Прозорро» не допустить ситуації відсутності чинного сертифіката відповідності КСЗІ на електронну систему публічних закупівель «Прозорро». Таким чином, найчастіше будуть проводитись процедури первинної авторизації та авторизації попередньо авторизованих майданчиків, за такої умови остання буде проводитись частіше першої, оскільки ця процедура буде застосовуватись у зв'язку з оновленням Державним підприємством «Прозорро» атестату відповідності КСЗI, який є строковим, і необхідністю приведення КСЗІ операторів електронних майданчиків у відповідність до атестата ITC «Прозорро». Водночас авторизовані електронні майданчики (що логічно вбачається, однак прямо не прописано у положеннях Порядку № 166) після зміни в КСЗІ ITC «Прозорро» набувають статусу попередньо авторизованих і повинні пройти процедуру авторизації попередньо авторизованого майданчика - подати в Мінекономіки копію атестату відповідності комплексної системи захисту інформації, побудованої на їхніх електронних майданчиках (протягом 12 місяців із дня отримання Державним підприємством «Прозорро» власного атестата, як того вимагає положення абзацу 3 пункту 3 Порядку № 166).

У період з 15 лютого 2019 р. по 15 лютого 2020 р. значного поширення набула процедура авторизації попередньо авторизованого електронного майданчика, оскільки всі попередньо авторизовані електронні майданчики активно почали запроваджувати власні КСЗІ на основі КСЗІ ITC «Прозорро». Необхідно відзначити, що не всі оператори електронних майданчиків встигли у 12-тимісячний строк побудувати КСЗІ на їхніх інформаційно-телекомунікаційних системах (наприклад, електронні майданчики «UBiz» [15], «25/8.АУКЦІОН»[16], «Акцепт»[17], «TendersAllbiz»[18], «OPEN TENDER»[19]), наслідком чого фактично було відключення вказаних електронних майданчиків від електронної системи закупівель «Прозорро».

Процедури авторизації електронних майданчиків $€$ різновидом адміністративних заявних процедур, тобто розпочинаються на підставі звернення оператора електронного майданчика (звернення зацікавленої особи). Перш ніж розпочинати процедуру авторизації, оператор електронного майданчика повинен підготувати матеріально-технічну базу електронного майданчика, в тому числі, як вже зазначалось вище, побудува- 
ти на електронному майданчику КСЗІ й отримати для неї атестат відповідності. Для цілей діяльності у сфері публічних закупівель комплексна система захисту інформації повинна бути погоджена не тільки в загальному порядку, а й з адміністратором електронної системи закупівель шляхом погодження технічного завдання на її створення.

Висновки. Резюмуючи вище викладене, можемо дійти висновку, що адміністративні процедури авторизації суб'єктів публічних закупівель (авторизаційні, субавторизаційні й деавторизаційні процедури) опосередковують публічно-правові відносини між Уповноваженим адміністративним органом (Міністерством розвитку економіки, торгівлі й сільського господарства України) й учасниками цих відносин (потенційними операторами електронних майданчиків, операторами авторизованих / попередньо авторизованих електронних майданчиків). Адміністративні процедури авторизації суб'єктів публічних закупівель спрямовані на надання, зміну або позбавлення статусу оператора електронної системи шляхом авторизації / попередньої авторизації електронної системи, зміну доменного імені авторизованої / попередньо авторизованої електронної системи. Указані процедури забезпечують дієвість побудованого механізму публічних закупівель.

Аналіз указаних процедур дає підстави стверджувати, що повноваження прийняття державно-владного рішення та повноваження визначення підстав для прийняття цього рішення у вказаних адміністративних процедурах розподілені між різними, хоч і інституційно-підпорядкованими суб'єктами. Так, державне підприємство «Прозорро» проводить тестування систем електронних майданчиків, виявляє їхню відповідність технічним вимогам, однак не уповноважене розглядати юридичні питання та приймати відповідні владно-управлінські рішення. Комісія при Мiнекономіки здійснює розгляд адміністративних справ на підставі поданих документів і висновків адміністратора, однак прийняті нею рішення мають рекомендаційний характер. Остаточне рішення приймає Мінекономіки, однак воно не розглядає справу по суті. Такий розподіл повноважень $€$ проявом принципу розподілу влади й позитивно впливає на вказану процедуру, зменшуючи корупційні ризики. Наявна законодавча вимога на кожному з етапів забезпечувати оприлюднення актів, якими етапи розпочинаються чи завершуються, сприяє прозорості процедури й покращує умови для контролю за законністю вказаної процедури.

\section{Jimepamypa}

1. Бандурка O.М., Тищенко М.М. Адміністративний процес : підручник для вищих навчальних закладів. Київ : Літера ЛТД, 2002. 288 с.

2. Висновок Головного науково-експертного управління Апарату Верховної Ради України на проєкт
Закону України «Про адміністративну процедуру» (реєстр. № 9456 від 28 грудня 2018 р.) від 01 березня 2019 р. База даних «Законодавство України». URL: http://w1.c1.rada.gov.ua/pls/zweb2/webproc4 1 ?pf $3511=6530$.

3. Вплив PROZORRO. Березень 2017 / Створено в рамках проєкту «Прозорість та підзвітність у державному управлінні та послугах» за фінансування USAID та UKAID. 12 c.

4. Даль В.М. Толковый словарь живого велико русского языка : В 4 т. Москва : Русский язык, 1980. T. $3.555 \mathrm{c}$.

5. Евгеньева А.П. Словарь русского языка : В 4 т. 2-е изд., испр. и допол. Москва : Русский язык, $1984.750 \mathrm{c}$

6. Етимологічний словник української мови : У 7 т. Т. 4 : Н - П / уклад. : Р.В. Болдирев та ін. ; ред. тому: В.Т. Коломієць, В.Г. Скляренко. Київ : Наук. думка, 2003. $656 \mathrm{c.}$

7. Звіт про результати аналізу щорічного звіту Мiністерства економічного розвитку і торгівлі України, що містить аналіз функціонування системи публічних закупівель та узагальнену інформацію про результати здійснення контролю у сфері закупівель, затверджений рішенням Рахункової палати від 28 травня 2019 p. № 12-2. URL: https://rp.gov.ua/upload-files/Activity/ Collegium/2019/12-2_2019/Zvit_12-2_2019.pdf.

8. Звіт про результати аудиту ефективності використання та розпорядження майном державного підприємства «ПРОЗОРРО», що має фінансові наслідки для державного бюджету, затверджений piшенням Рахункової палати від 29 листопада 2018 р. № 30-4. URL: https://rp.gov.ua/upload-files/Activity/ Collegium/2018/30-4_2018/Zvit_30-4_2018.pdf.

9. Кодекс адміністративного судочинства України : Закон України від 06 липня 2005 р. № 2747-IV / Bepховна Рада України. URL: https://zakon.rada.gov.ua/ laws/show/2747-15.

10. Кулак Н.В. Електронне забезпечення сфери здійснення державних закупівель в Україні : дис. ... канд. наук з державного управління : 20.00.02. Харків, 2015. $238 \mathrm{c.}$

11. Науково-практичний коментар до проєкту Закону України «Про адміністративну процедуру» / авт. колектив О.Ф. Андрійко, В.М. Бевзенко та ін. ; за заг. ред. В.П. Тимощука. Київ : ФОП Мишалов Д.В., 2019. $460 \mathrm{c}$.

12. Ожегов С.И. Словарь русского языка. Москва : Сов. Энциклопедия, $1973.846 \mathrm{c}$.

13. Питання Міністерства розвитку економіки, торгівлі та сільського господарства : Постанова Кабінету Міністрів України від 11 вересня 2019 р. № 838 / Кабінет Міністрів України. URL: https://zakon.rada.gov. ua/laws/show $/ 838-2019-\%$ D0 $\%$ BF.

14. Постанова Шостого окружного адміністративного суду від 05 березня 2019 р. у справі № 826/12827/18. ЄӘиний державний реєстр судових рішень. URL: http://reyestr.court.gov.ua/Review/80384228.

15. Про відключення попередньо авторизованого електронного майданчика від електронної системи закупівель : Наказ Міністерства економіки від 03 квітня 2020 p. № 615-20. URL: https://drive.google.com/file/ d/1iE4iSQM838ZWK_dgyNyMTJBnkZ1_NYuD/view.

16. Про відключення попередньо авторизованого електронного майданчика від електронної системи закупівель : Наказ Міністерства економіки від 07 квітня 2020 p. № 644-20. URL: https://drive.google.com/file/ d/1EwTXhJvqTzl68DZzycMEqtfMpwr8ggD8/view.

17. Про відключення попередньо авторизованого електронного майданчика від електронної системи за- 
купівель : Наказ Міністерства економіки від 07 квітня 2020 p. № 645-20. URL: https://drive.google.com/file/ d/1wSFWDzLmTXPshF-mHvbYUMfwH3WhdGQo/view.

18. Про відключення попередньо авторизованого електронного майданчика від електронної системи закупівель : Наказ Міністерства економіки від 07 квітня 2020 p. № 646-20. URL: https://drive.google.com/file/ d/1zUGtq278JmbfxyXF8cbKBSiHLfyh9JLY/view.

19. Про відключення попередньо авторизованого електронного майданчика від електронної системи закупівель : Наказ Міністерства економіки від 07 квітня 2020 p. № 647-20. URL: https://drive.google.com/file/ d/1r6VFmOJJpLYGvOSFqzMF Wv0UabdSwV6/view.

20. Про внесення змін до Порядку функціонування електронної системи закупівель та проведення авторизації електронних майданчиків : Постанова Кабінету Міністрів України від 01 липня 2016 р. № 396 / Кабінет Міністрів України. URL: https://zakon.rada.gov.ua/ laws/show/396-2016-\% D0\% BF\#Text.

21. Про внесення змін до Порядку функціонування електронної системи закупівель та проведення авторизації електронних майданчиків : Постанова Кабінету Міністрів України від 10 липня 2019 р. № 704 / Кабінет Міністрів України. URL: https://zakon.rada.gov.ua/ laws/show/704-2019-\% D0\% BF\#n2.

22. Про затвердження Порядку функціонування електронної системи закупівель та проведення авторизації електронних майданчиків : Постанова Кабінету Міністрів України від 24 лютого 2016 р. № 166 / Кабінет Міністрів України. URL: https://zakon.rada.gov. ua/laws/show/166-2016- $\%$ D0 $\%$ BF.

23. Про затвердження Примірного договору про надання доступу до модуля електронного аукціону та бази даних : Наказ Міністерства економічного розвитку і торгівлі України від 28 березня 2018 р. № 435. URL: http://search.ligazakon.ua/1_doc2.nsf/link1/ ME180317.html.

24. Про захист інформації в інформаційно-телекомунікаційних системах : Закон України від 05 липня 1994 р. № 80/94-BP / Верховна Рада України. URL: https: / zakon.rada.gov.ua/laws/show /80/94-\% D0\% B2\% D1\% 80/ed20140419\#n56.

25. Проєкт Адміністративно-процедурного кодексу України : Законопроєкт від 29 грудня 2001 p. № 8413. База даних «Законодавство Укра їни». URL: http://w1.c1.rada.gov.ua/pls/zweb2/ webproc4 1?pf3511=11716.

26. Проєкт Адміністративно-процедурного кодексу України : Законопроєкт від 29 квітня 2004 р. № 5462. База даних «Законодавство України». URL: http://w1.c1.rada.gov.ua/pls/zweb2/webproc4 2?id= $\&$ pf $3516=5462 \& \mathrm{skl}=5$.

27. Проєкт Адміністративно-процедурного кодексу України : Законопроєкт від 18 липня 2008 р. № 2789. База даних «Законодавство Украӥни». URL: http://w1.c1.rada.gov.ua/pls/zweb2/webproc4 1?\% $20 \mathrm{pf} 3511=33073$.

28. Проєкт Адміністративно-процедурного кодексу України : Законопроєкт від 03 грудня 2012 р. № 11472. База даних «Законодавство Украӥни». URL: http://w1.c1.rada.gov.ua/pls/zweb2/webproc4 1 ?pf $3511=44893$.

29. Проєкт закону «Про адміністративні процедури» : Законопроєкт від 14 травня 2020 р. №3475. База даних «Законодавство України». URL: http://w1.c1. rada.gov.ua/pls/zweb2/webproc4_1?pf3511=68834.

30. Прожкт закону «Про адміністративні процедури» : Законопроєкт від 28 грудня 2018 р. № 9456 . База даних «Законодавство України». URL: http://w1.c1. rada.gov.ua/pls/zweb2/webproc4_1?pf3511=65307.
31. Куйбіда Р.О. Проблема адміністративного договору у законодавстві, теорії, на практиці. Державні закупівлі Украӥни. 2008. № 12 (54). С. 28-32.

32. Рішення Окружного адміністративного суду міста Києва від 14 листопада 2018 р. у справі № 826/12827/18. Єәиний державний реєстр судових рішень. URL: http://reyestr.court.gov.ua/Review/ 78087176

33. Селіванова Н.П. Адміністративно-правове забезпечення функціонування системи електронних закупівель в Україні : дис. ... канд. юрид. наук : 12.00.07 ; НДІ публ. права. Київ, 2017. 222 с.

34. Словник української мови : в 11 т. / АН УРСР, Ін-т мовознавства ; ред. кол. : І.К. Білодід (гол.), А.А. Бурячок, В.О. Винник та ін. Київ : Наукова думка. Т. 8 : Природа - Ряхтливий / ред. тому : В.О. Винник, В.В. Жайворонок, Л.О. Родніна та ін. 1977.927 с.

35. Ковальчук М.О. Чим відрізняється авторизація від аутентифікації? Стаття від 30 вересня 2014 р. WordPress : вебсайт. URL: https://kovalchukmm14. wordpress.com $/ 2014 / 09 / 30$.

36. Шкарупа В.К., Лагода О.С. Адміністративна процедура, її значення та місце в адміністративно-процесуальній діяльності. Право України. 2006. № 6 . C. $12-14$.

\section{Анотація}

Оврамець Ю. О. Зміст та етапи адміністративної процедури авторизації електронних майданчиків. Стаття.

У статті розглянуто поняття, сутність та етапи процедури авторизації електронних майданчиків як адміністративної процедури, розкрито її співвідношення з процедурою попередньої авторизації та процедурою авторизації попередньо авторизованого електронного майданчика. У статті автор досліджуе нормативно-правове регулювання процедур авторизації електронних майданчиків і виявляє ряд характерних проблем, зокрема пов'язаних з існуванням категорій, які не знайшли свого відбиття в системі закону України «Про публічні закупівлі». Автором детально розглянуто процес проведення адміністративної процедури авторизації електронних майданчиків, 3 огляду на що запропоновано систему етапів вказаної адміністративної процедури. За наслідками пошуку актів правозастосування автором викладено основну проблематику вказаного виду адміністративних процедур у сфері публічних закупівель, пов'язану із запровадженням комплексної системи захисту інформації, формуванням статусу попередньо авторизованого майданчика й переходу до статусу авторизованого майданчика.

У результаті проведеного дослідження автором доведено, що адміністративні процедури авторизації суб'єктів публічних закупівель (авторизаційні, субавторизаційні й деавторизаційні процедури) опосередковують публічно-правові відносини між Уповноваженим адміністративним органом (Міністерством розвитку економіки, торгівлі й сільського господарства України) й учасниками цих відносин (потенційними операторами електронних майданчиків, операторами авторизованих / попередньо авторизованих електронних майданчиків). Адміністративні процедури авторизації суб'єктів публічних закупівель спрямовані на надання, зміну або позбавлення статусу оператора електронної системи шляхом авторизації / попередньої авторизації електронної системи, зміну доменного імені авторизованої / попередньо авторизованої електронної системи.

Ключові слова: адміністративна процедура, авторизація електронного майданчика, попередня авториза- 
ція, авторизація попередньо авторизованого майданчика, етапи адміністративної процедури авторизації електронних майданчиків.

\section{Summary}

Ovramets $\mathrm{Yu}$. $\mathrm{O}$. Content and stages of the administrative procedure for authorization of electronic platforms. - Article.

The article considers the concept, essence and stages of the procedure of authorization of electronic platforms as an administrative procedure, reveals its relationship with the procedure of pre-authorization and the procedure of authorization of pre-authorized electronic platform. In the article the author reveals the legal regulation of electronic platform authorization procedures and identifies a number of typical problems, in particular, related to the existence of categories that are not reflected in the system of the law of Ukraine "On Public Procurement". The author considers in detail the process of conducting the administrative procedure of authorization of electronic platforms, taking into account the proposed system of stages of this administrative procedure. According to the results of the search for law enforcement acts, the author highlights the main issues of this type of administrative procedures in the field of public procurement, related to the introduction of a comprehensive information security system, the formation of pre-authorized platform status and transition to authorized platform status.

As a result of analysis, the author proved that the administrative procedures for authorization of public procurement entities (authorization, sub-authorization and de-authorization procedures) mediate public relations between the Authorized Administrative Body (Ministry of Economic Development, Trade and Agriculture of Ukraine) and participants in these relations (potential operators of electronic platforms, operators of authorized/ pre-authorized electronic platforms).Administrative procedures for authorization of public procurement entities are aimed at granting, changing or revoking the status of the electronic system operator by authorizing/pre-authorizing the electronic system, changing the domain name of the authorized/pre-authorized electronic system.

Key words: administrative procedure, authorization of electronic platform, preliminary authorization, authorization of pre-authorized platform, stages of administrative procedure of authorization of electronic platforms. 